\title{
The Sustainable Entrepreneur: Balancing People, Planet and Profit
}

\author{
Dave Feldman (Livability Project)
}

KEYWORDS: Management of Companies \& Enterprises, Entrepreneurship, Organization, Strategy.

Entrepreneurs and business leaders are blessed and cursed with thinking about their businesses 24 hours a day. It becomes their life focus.

What is it that consumes them? Bottom line? Employee well-being? Customer acquisition? Environmental impacts of their operations? Brand and reputation? The answer most likely is yes, at least to some degree, to all of the above. A successful entrepreneur is one who strives for many diverse objectives -- what one might call a "sustainable entrepreneur."

\section{What is a sustainable entrepreneur?}

First, an entrepreneur is a person who organizes and operates a business or businesses, taking on greater than normal financial risks in order to do so. They are highly motivated with a "get it done" mindset. They not only have ambitious goals but also an innate ability to execute and build value over time. Successful entrepreneurs have a broad view of their business and understand or hire to build requisite technical skills marketing, finance, operations,

Sustainability is often confused with concepts of "going green" or more environmentally friendly. By all means, protecting the environment is of paramount concern to all of us for the simple reason that every business (and life) coexists with a healthy environment. However, sustainability is broader. One definition is to maintain over a long time the ability to keep going and support, uphold or bear the weight of a structure. This certainly applies to business. Another definition often used is to "meet the needs of the present world without compromising the ability of the future generations to meet their own needs."

In business, it can be defined as Triple Bottom Line, addressing three highly interconnected areas - People, Planet and Profit. Triple Bottom Line (otherwise noted as TBL or $3 B L$ ) is an accounting framework with three

parts: social, environmental and economic. Many entrepreneurs have adopted this framework to measure their performance with a broader perspective and create greater business value.

So why is sustainability and Triple Bottom Line important as an opportunity for entrepreneurs? There are multiple reasons but five key ones are:

Changing Consumer Tastes - Millennial and other consumers have higher expectations of those they buy from now. They expect more from their products and companies who sell them. Consumers are demanding new approaches to everything ranging from organic food to greener buildings, more energy efficient appliances to more responsibly sourced products.

Social Media - More than ever before, entrepreneurs need to engage through technology as real-time connections replace mass-target communications. Relationships must be built on trust and transparency. Social media, one of the fastest growing industries, is more than a marketing tool. It allows entrepreneurs to share their views on important issues to their core audience and interact freely and quickly.

Supply Chain - Suppliers and corporate customers are increasingly requiring sustainable practices from their vendors. Products are only as good as their components, raw materials, transportation and logistics. Executives see sustainable supply chains as a direct link to long-term profitability, value creation and opportunities to create competitive advantage in product development and process innovation.

Financial - Many agree that building a business around TBL practices have a positive economic impact because it, makes them more competitive, delivers greater efficiencies and sparks innovation -- all drivers of profitability. Quantifiable are the efficiencies produced through streamlined efforts, waste reductions 
and resource conservation. Less so but equally important is the increased value to the brand and company image.

Better workplace - Many people want to work for companies that make the planet better. They want to be part of a company that operates ethically and acts with integrity, cares about the people it employs and makes products that enhance people's lives. Entrepreneurs respectful of the environment and its employees will attract the caliber of people whom helps a business expand.

Sustainable entrepreneurs introduce products and services to existing markets and develop new consumers wanting sustainable lifestyles. Though they play a critical role in change, they recognize that their businesses must create value for customers and investors. They ask questions and put themselves in a position to take advantage of "sustainability" as a market. They create opportunities to address problems around clean air, water and conservation, improving health, more efficiently designed cities and energy efficiency.

\section{Inspiration from leaders}

I had the fortune of interviewing several leading sustainability entrepreneurs for EIX. Here some of their insights on how sustainable entrepreneurship works for them, and links to their full interviews.

\section{Seth}

Goldman

(https://eiexchange.com/content/122-mission-in-a-bottlea-discussion-with-honest-teas-seth-goldman-)

Founder of Honest Tea and executive Chairman of Beyond Meat sees entrepreneurship as a way to impact change through market-based solutions. He states, "For us that mission element defines how we grow. When you have an authentic belief behind something, it leads to an authentic brand message. If you can connect those beliefs to a product and then help consumers connect to it, it can be impactful."

\section{Marnie}

Abramson,

(https://eiexchange.com/content/123-marnie-abramsoncaring-for-the-bottom-line-and-the-planet-) CEO of Next Gen Partners, shares, "When I first started in real estate, we wanted to calculate the benefits of being in a healthy building. It was something fundamentally we believed in and was a way of approaching the market that others weren't looking at. If we could re-position the way they were evaluating their business decisions we could move them closer into alignment with sustainability and business. I believed in the math and science. The first page of my proposals is your ROI, NPV, financials and the next page is your environmental impact."

ScottNash,(https://eiexchange.com/content/124-greengiant-grocer-scott-nash-on-organic-growth)founderand CEO of Mom's Organic market, adds "getting into organic foods was my passion, I 'owned' it. I have been hearing for 20 years that organics was trending but I believed it's where the world was going. Our purpose is to protect and restore the environment. It doesn't have a lot to do with selling groceries, does it? Every decision we make is pointed at accomplishing our purpose."

Sustainability can be confusing and challenging. Socially conscious decisions are not always clear and not all consumers care about their choices.

The movement however, continues to grow.

Fortunately a new model is emerging, an entity called the benefit corporation, which has been written into law in many states. A benefit corporation is a new class of a corporation that 1) creates a material impact on society and the environment, 2) redefines fiduciary responsibility to non-financial stakeholders and 3) reports on social and environmental standards. It is clearly trending.

The pace of change will continue and it is encouraging that people will increasingly alter their buying, eating and living behaviors as they understand how their decisions impact the world. As a Sustainable Entrepreneur, more information is readily available and companies have never been in a better position to adapt to this constantly evolving demand.

Additional Search Terms: Sustainable, sustainability, climate change, environment, environmental, sustainable business, helping climate change, global warming 